\title{
Blended undervisning og metarefleksioner
}

\section{Kompetenceudvikling i tværprofessionelt underviserregi}

Anne Winther Jensen, Professionshøjskolen Absalon

Jan Ohrt Nissen, Professionshøjskolen Absalon

\section{Abstract}

Artiklen formidler erfaringer med at gennemføre et forløb for opkvalificering af elæringsundervisere (blended undervisning) fra fire uddannelser på Professionshøjskolen Absalon. Forløbet var del af et tre-årigt udviklingsprojekt. Projektets teoretiske forankring var Design Based Research og pragmatisme, og forløbet for underviserne var bygget op med henblik på udvikling af undervisernes egne blendede forløb og e-læring generelt i Absalon. En fællesdel i forløbet var derudover udvikling af en didaktisk ramme ift. blendede forløb, mens det for de deltagende undervisere indebar udvikling af både e-didaktiske og teknologiske kompetencer. Erfaringerne fra forløbet peger på, dels det udbytterige i samtidigt at opkvalificere underviserne ift. e-didaktik og teknologi, dels at knytte udviklingsdelen tæt til undervisernes egen undervisningsvirkelighed. Derudover peger erfaringerne på fordele ved at lade undervisere fra forskellige professionsområder indgå i fælles opkvalificeringsforløb, da divergerende holdninger til blended læring sættes i spil og gensidigt udfordrer hinanden. En hel særlig erfaring er betydningen af tilbagevendende metarefleksioner ift. undervisernes egen praksis med studerende ud fra erfaringer med selv at være "studerende" i opkvalificeringsforløbet, idet metarefleksionerne øjensynligt befordrer en udvikling af den enkelte undervisers undervisning, hvor fokus er på den studerendes perspektiv.

\section{Engelsk abstract}

This article accounts for experiences with conducting a qualification course for e-learning/blended course teachers from four different programs at Absalon University College. The course was part of a three-year development project. The theoretical foundation of the project was Design Based Research and pragmatism, and the course had the dual purpose of 1) the improvement of the teachers' own blended courses, and 2) the improvement of e-learning at Absalon University College in a more general perspective. A joint part of the course was for the participating teachers and the project group to develop a learning design framework in relation to blended courses and for the participating teachers it included developing both e-learning design competencies as well as technological competencies. The course revealed the benefits of simultaneously upgrading teachers' skills in e-learning design and technology, and to link the development part closely to the teachers' own teaching reality. In addition, it showed that it is beneficial to include teachers from different programs in joint qualification courses, as divergent attitudes towards blended learning are put into play, mutually challenging each other. Finally, the gained experience points to the importance of meta-reflections of the teachers' own practice with students, based on experiences of "being students" themselves in the qualification course. The meta-reflections seem to promote a studentcentered teaching perspective. 


\section{Introduktion}

I større undervisningsinstitutioner, hvor forskellige uddannelser er samlet som fx på professionshøjskolerne, kan det være en udfordring på tværs af uddannelserne at skabe og vedligeholde en fælles profil ift. uddannelsernes tilbud om blended learning/e-læring. Uddannelserne har forskellige forankringer i henholdsvis det humanistiske, naturvidenskabelige og samfundsfaglige område, har forskellig historie og har evt. tilbudt blended learning/e-læring i en kortere eller længere årrække. En vis ensartethed giver professionshøjskolens ledelse bedre overblik og handlemuligheder ift. styring, kvalitet og udvikling. Endvidere kan en vis ensartethed på tværs være ønskeligt ift. at profilere tilbuddet, bl.a. når det gælder om at tiltrække studerende til tilbuddet, idet der dermed fx overskueligt kan annonceres på professionshøjskolens samlede side. Derudover opstår der ikke forvirring vedrørende fremmødefrekvens, studyload mv., hvis ansøgeren orienterer sig på forskellige uddannelsers undersider, og studievejlederne vil have nemmere ved at orientere potentielle ansøgere.

Netop ønsket om kvalitetshøjnelse, ensartethed og bedre mulighed for styring og udvikling bevirkede, at Professionshøjskolen Absalon i 2017 etablerede et udviklingsprojekt, Absalon E, der skulle fremme de nævnte faktorer. Projektet var planlagt som 3 -årigt og forankret i organisationens strategiske indsats "Engagerende undervisning"1, og formålet var at skabe en vis genkendelighed i e-læringsudbuddet på tværs af uddannelserne og at "udvikle og virkeliggøre engagerende e-læring ved Absalon, (...), der systematisk inkluderer samarbejde og videndeling i både fysiske samt synkrone og asynkrone online rum." (Nortvig, 2017), samt "at der sikres og implementeres en praksis for professionelle praksisfællesskaber blandt e-læringsunderviserne, og at dette understøttes af de understøttende funktioner samt af uddannelsesledere og -chefer i de enkelte uddannelser.” (Ibid.). I Absalon er e-læring synonym med blended learning, så når der i det følgende står e-læring, er der altså tale om undervisning med en kombination af fremmøde og virtuelle uger. Fremmødeprocenten varierer på de forskellige uddannelser, men udgangspunktet fra ledelsens side er $25 \%$ fremmøde og $75 \%$ virtuel undervisning (UCSJ Kvalitet, 2015).

Professionshøjskolen Absalon har 11 professionsuddannelser med i alt ca. 8.500 studerende fordelt på ni lokationer. Over en årrække er en del af uddannelserne blevet udbudt som e-læring, og heraf blev seks uddannelser udvalgt til at deltage i udviklingsprojektet: Sygeplejerske-, ernærings- og sundheds, socialrådgiver-, pædagog-, lærer- og administrationsbacheloruddannelsen. Disse uddannelser har haft e-læringsudbud i mellem 4 og 17 år; det samlede antal studerende i disse e-læringsudbud er ca. 1000, og det samlede antal undervisere involverede i disse e-læringsudbud (nogle kun med fă timer) er 99 (tal pr.1.1.18, projektets afdækningsfase). Projektets faser var "Afdækning af bestående praksis", "Kompetenceudviklingsforløb for e-læringsundervisere" og en "Implementeringsfase med vidensgenerering og -spredning". Projektet var ledet af en projektleder og en projektgruppe.

Denne artikel fokuserer på den midterste fase, kompetenceudviklingsforløbet for e-undervisere ift. edidaktik og teknologikompetencer, og formidler erfaringer med at etablere og afholde et sådant forløb

${ }^{1}$ Engagerende undervisning har som målbillede (phabsalon.dk): Vi sætter ambitiøse mål for undervisningen og har tydelige forventninger til de studerendes indsats. Vi engagerer de studerende og understøtter deres læreprocesser på forskellige måder og niveauer, der matcher studerende med mange forskellige forudsætninger.

Undervisningen fremmer læringsfællesskaber og alle studerendes aktive deltagelse i undervisningen. De studerende møder undervisere, der er vidende og engagerende både fagligt, pædagogisk og didaktisk. 
for undervisere på tværs af uddannelserne. Artiklens omdrejningspunkter er spørgsmålene om, hvordan man kan tilstræbe, at uddannelserne, deres forskellighed til trods, ser sig anerkendt i og engagerer sig i en udviklingsproces, herunder specifikt kompetenceudviklingsforløbet, samt hvordan man helt konkret kan tilrettelægge kompetenceudvikling, så de implicerede deltagere oplever opkvalificeringen som relevant og værd at videreføre.

Status på Absalons teknologiske ramme for undervisning var på tidspunktet for projektstart og kompetenceudviklingsforløb - både for ordinær undervisning og e-læring/blended learning - det Salmon (2014; 2016) beskriver som udnyttelse af organisationens eksisterende kernekompetencer i et universitetsejet LMS, Fronter, med heraf trinvis udvikling fra campussitueret læring til blended og distance learning. Fronter havde været organisationens LMS i ca. 10 år, og hensigten var inden for en "kortere årrække" at udskifte dette til et mere tidssvarende LMS. Mens behov og muligheder blev overvejet og undersøgt havde systemet fået en internt initieret æstetisk og mere tidsvarende opdatering, således at de "rum", de studerende mødte, fremstod "website"-agtige og således lidt mere nutidige end det underliggende mappesystem, som Fronter består af, og som før var det eneste synlige. Som Salmon påpeger, er mulighederne i en sådan teknologisk situation for underviserne at benytte diverse "add-ons" ift. at bedrive og udvikle e-læringsundervisning. Den aktuelle situation, som projektet skrev sig ind i, var således karakteriseret af et forældet LMS, hvor organisationens digitale center havde indlejret diverse programmer, og hvor også de individuelle undervisere indlejrede forskellige programmer alt efter, hvad de så som formålstjenligt i deres konkrete undervisning. Undervisernes teknologiske kompetencer ift. at benytte "add-ons" var meget forskellig, hvorved de studerende undervejs i deres uddannelse kunne opleve stor variation ift. teknologinddragelse og udnyttelse. Projektets mål var således også at igangsætte en udvikling på dette felt2

Artiklens fokus er som nævnt det kompetenceudviklingsforløb, som skulle bidrage til udvikling på tværs af uddannelserne og specifikt til udvikling af undervisernes kompetencer. Dette forløb var jf. ovenstående uddrag fra projektbeskrivelsen og faseinddelingen kun et af flere tiltag, og indledningsvis bliver det forudgående forløb kort skitseret, således at tiltagene i selve kompetenceudviklingsforløbet er kontekstplaceret. Dernæst beskrives projektets og dermed kompetenceudviklingsforløbets teoretiske og metodiske forankring, hvorefter forløbet, som det var planlagt, udfoldes. Herefter følger et afsnit med nedslag på afviklingen og de forhold, som har givet projektgruppen anledning til særlige refleksioner. Afslutningsvis samles der op på erfaringer fra forløbet, og opmærksomhedspunkter og udviklingsmuligheder ift. et kompetenceudviklingsforløb af lignende karakter udpeges.

2 Projektets succeskriterier var:

- at mindst 50\% af underviserne på de enkelte uddannelsers e-læringsformat har deltaget i udvikling og afvikling af e-didaktiske designs

- at mindst 50\% af underviserne på de enkelte uddannelsers e-læringsformat har deltaget i tekniske kurser.

- $\quad$ Alle undervisere har deltaget i videndeling med kolleger om e-læring

- Alle undervisere arbejder med 5 fælles principper for e-læring i Absalon

- Endvidere er succeskriteriet, at en strategi for fortsat udvikling, videndeling og sparring på e-didaktisk design er vedtaget af ledelsen, og der er lavet en implementeringsplan for dette på de enkelte uddannelser. 


\section{Del af udviklingsprojektet der gik forud for kompetenceudviklingsforløbet}

Kompetenceudviklingsforløbet for undervisere lå i projektets andet år, og var som nævnt et delelement i udviklingsprojektet. Kompetenceudviklingsforløbet blev tilrettelagt på baggrund af projekts første fase og første år, der omhandlede afdækning af eksisterende praksisser og holdninger til e-læring. Afdækningen bestod af forskellige undersøgelser: Der blev udsendt spørgeskema til uddannelsernes uddannelsesledere, der blev foretaget fokusgruppeinterview med e-læringsundervisere på hver af de deltagende uddannelser, der blev afholdt fremtidsværksstedsinspirerede workshops også med undervisere på hver uddannelse samt udsendt surveys til alle e-læringsundervisere og e-studerende på de seks deltagende uddannelser. De nævnte tiltag og deres formål skitseres i det følgende kort:

Spørgeskemaet til uddannelseslederne omfattede spørgsmål om e-læringsundervisernes ansættelsesforhold (tidsbegrænsede, adjunkter, lektorer), og mundtligt blev der indhentet info om antal studerende og e-læringsudbuddets startår. Formålet var at få overblik over, hvordan de enkelte uddannelser bedrev e-læring/blended learning mao. få overblik over, hvor forskelligartede tilbuddene var.

Formålet med de 6 fokusgruppeinterview, ét på hver uddannelse med 4-6 undervisere, var at få indsigt i undervisernes praksis og deres syn på, hvad der er god/mindre god e-læring. Interviewene blev videooptagede, og fokusgruppeformen var valgt, fordi ønsket var at producere empiri om, hvordan gruppen af undervisere på hver enkelt uddannelse forstod egen undervisning som del af den fælles opgave at udbyde e-læring (Halkier 2016). Mhp. på at få både individuelle og fælles forståelser samt diskussioner frem var fokusgruppeinterviewet udformet som aktiviteter (Colucci, 2007). På baggrund af videooptagelserne blev der for hver uddannelse af projektgruppen udfyldt et skema med kategorierne: Eksempler på vellykket e-læring, Eksempler på mindre vellykket e-læring, Forudsætninger for god elæring, De særlige udviklingspotentialer/svagheder i uddannelsen, Rangordningerne individuelt og fælles.

De fremtidsværkstedsinspirerede workshops (Jungk, 1998) havde til formål, dels at afdække eksisterende praksis, dels at afdække, hvor de deltagende undervisere ønskede uddannelserne skulle bevæge sig hen. Der deltog mellem 4-8 undervisere på hver af workshoppene, der indeholdt 4 processer: En kritikfase, en visionsfase, en konkretiseringsfase samt en behovsfase. Undervejs blev der skrevet på vægpapirer, der blev fotograferet, og som af koordinatorgruppen blev analyseret for de enkelte uddannelser og på tværs.

Projektgruppen udsendte spørgeskemaer til alle fuldstids-e-læringsstuderende og alle elæringsundervisere. Gruppen af førstnævnte var på i alt 983, og heraf besvarede 286 skemaet, hvilket gav en svarprocent på $29 \%$. Det samlede antal e-undervisere var på 99, hvoraf 67 responderede med en svarprocent på $67 \%$ til følge. Det havde været ønskeligt om svarprocenterne var højere, men med henvisning til forskning (Morton et. al., 2012; Wright 2015; Curtin et al., 2000;) kan man påpege, at den lave svarprocent indikerer en større risiko for lav validitet, men ikke i sig selv er udtryk for lav validitet.

Spørgeskemaerne havde fokus på anvendelsen af teknologi i undervisningen og indeholdt både kvantitative og kvalitative spørgsmål og var udarbejdet med inspiration fra National Survey of Student Engagement, NSSE (nsse.indianna.edu). De kvalitative spørgsmål til studerende angik bud på forbedringer og gav mulighed for at tilkendegive negative såvel som positive oplevelser med e-læring. Svarene var anonyme fra undervisere såvel som studerende.

Undersøgelserne viste, at uddannelserne bedrev e-læring med stor forskellighed i fx fremmødefrekvens og fleksibilitet i "tid" - alle havde fleksibilitet i "sted"- og hvad angår opfattelsen af studentergruppen på 
e-læring var der også store forskelle - på én uddannelse synes det at være de særligt dygtige, selvkørende og målrettede, der vælger e-læring, mens der i den anden ende af spektret på én uddannelse blev talt om en overvægt af studiemæssigt svage studerende med diverse problematikker. Undersøgelserne - især manifesteret i fokusgruppeinterviewene - viste endvidere, at der også internt på uddannelserne var forskelligheder mellem underviserne, fx i opfattelsen af hvad "god e-læring” er og synet på vigtigheden af henholdsvis de virtuelle perioder vs. faf-undervisningen. Mange udfordringer gik dog igen mellem uddannelserne, $\mathrm{fx}$ at engagere de studerende i online seancer på fx Adobe Connect samt få de studerende til at acceptere gruppearbejdsformen, som på alle uddannelser er udbredt. Sidstnævnte berører elementet "forventningsafstemning", som peger på udfordringer i forbindelse med annoncering over for potentielle ansøgere, jf. introduktionen til denne artikel. Næsten alle undervisere på tværs af uddannelser ønskede opkvalificering ift. e-didaktik og ift. brugen af diverse programmer, dvs teknologisk opkvalificering herunder en kobling mellem det didaktiske og det teknologiske. Langt de fleste undervisere så ligeledes et potentiale i opkvalificering sammen med undervisere fra andre uddannelser, idet e-læringsundervisergruppen på de fleste uddannelser er ret lille, og man derfor savner ekstern inspiration.

På basis af ovennævnte undersøgelser og deres resultater blev kompetenceudviklingsforløbets præcise indhold tilrettelagt. Forløbets teoretiske og overordnede metodiske tilgang lå dog fast forud for undersøgelserne (i projektbeskrivelsen), og teorirammen var en rød tråd gennem hele projektet. Kompetenceudviklingsforløbets mål var (Nortvig, 2017):

1. at deltageren opnår viden om e-didaktik generelt samt viden om, hvordan man som underviser kan designe blended learning, der fokuserer på interaktion og oplevelse af tilstedeværelse mellem deltagerne.

2. at deltageren tilegner sig færdigheder til at udvælge og benytte redskaber til understøttelse af undervisning og læring i både f2f og virtuelle uger.

3. at deltageren opnår kompetence til gennem e-didaktiske eksperimenter og refleksioner at bidrage til udvikling af fælles overordnet e-didaktisk framework til Professionshøjskolen Absalons e-læringsuddannelser.

Næste afsnit er en skitsering af den teoretiske ramme, som den konkrete planlægning talte ind i.

\section{Udviklingsprojektets teori og metode}

Absalon Es arbejde med at få kendskab til, hvordan blended learning af aktørerne operationaliseres i Absalons miljø, hvilke problemer aktørerne ser, og hvordan et kompetenceforløb kan struktureres, tog afsæt i metoden Design Based Research (DBR), der har pragmatismen som overordnet ramme (Barab \& Squire, 2004; Wang \& Hannafin, 2005). Vi arbejdede i projektgruppen derfor abduktivt, dialogisk, demokratisk og antifundamentalisk mod et ikke-statisk svar på vores divergerende forespørgsler. Målet for projektgruppen med at anvende DBR som metode var ikke, at der skulle opnås endegyldige svar mht. blended learning på Absalon, da dette i sig selv anses som en problematisk tænkning inden for pragmatismen (Cherryholmes, 1999; Putnam, 1995; Rorty, 1982). I stedet så vi mod de konsekvenser, som handlende oplever i miljøet, og hvordan de gætter mod fremtiden, og hvorvidt ændrede handlinger også vil være hensigtsmæssige for aktørerne i miljøet fremadrettet (Barab \& Squire, 2004). DBR blev anvendt som en systematisk metode, hvor projektgruppen i samspil med især underviserne kunne tilpasse og eksperimentere med forskellige idéer, med det formål at udvikle Absalons E-læringsmiljø.

DBR fordrer handlinger foretaget i miljøet af miljøet (Anderson \& Shattuck, 2012), hvilket adskiller metoden fra mere nomotetiske, dualistiske og induktive tilgange (Cherryholmes, 1994; Pool \& Laubscher, 2016). Projektgruppen i Absalon E lagde derfor op til, via DBR, at underviserne ikke blot skulle være medskabere af, hvad der virker, men også samtidig kunne udvikle fremadrettede og kontinuerlige handlemuligheder i miljøet, som ville bestå efter projektets afslutning. Da DBR og 
pragmatismen ikke kan opfattes som en klar programmatisk tilgang, fordi projektgruppen og især deltagernes erfaringer ville præge handlemulighederne, så vi positivt på gentagne tilpasninger og eksperimenteringer i den abduktive proces. Erfaringsgrundlaget og miljøet kunne betragtes som værende i konstant bevægelse, og generaliserbarheden af, hvad der virkede hensigtsmæssigt for nogle, ville måske øges (Anderson \& Shattuck, 2012). Fremgangsmåden for projektet via DBR var (1) en start med en problematisering i Absalons E-læringsmiljø af aktørerne i miljøet (jf. omtalen af workshoppene). (2) Udvikling af løsningsforslag. (3) Gentagende afprøvninger i miljøet. (4) Refleksioner over designprincipper og implementeringsmulighederne.

Ovennævnte fremgangsmåde åbnede for mange handlemuligheder for de involverede aktører - her specifikt underviserne - hvor egne erfaringer var med til at præge opfattelsen af, hvad der virkede. I et forsøg på at imødegå den ofte misforståede pragmatiske tænkning om at "It's true (for you) if its good for you" (Putnam, 1995, s. 51), lægger DBR som metode op til gentagende afprøvninger i et kollaborativt miljø (Wang \& Hannafin, 2005). Denne fælles søgen efter nye løsninger på nuværende og fremtidige problemstillinger blev af projektgruppen tillagt en teoretisk ramme ud fra Community of Inquiry (CoI) modellen (Garrison, 2016). CoI-modellen, der også er funderet i pragmatismen, anvendtes i tråd med principperne i DBR for at etablere en fælles talegenre og en tråd til allerede etableret designudvikling (design defineres nedenfor) i blended uddannelsesmiljøer, som den abduktive proces kunne tage afsæt i. CoI-modellen i samspil med DBR skal altså opfattes som en måde, hvorpå underviserne ud fra en fælles metodik kunne udfordre hinandens etablerede handlemønstre og deraf udvikle nye (Barab \& Squire, 2004; Garrison, 2016; Wang \& Hannafin, 2005).

\section{Kompetenceforløbets opbygning}

I kompetenceudviklingsforløbet deltog fire af de seks projektdeltagende uddannelser; de to resterende havde uddannelsesinterne forløb kørende, som de ønskede at fortsætte med. Deltagende uddannelser i kompetenceudviklingsforløbet var således: Pædagoguddannelsen, sygeplejerskeuddannelsen, socialrådgiveruddannelsen og ernæring- og sundhedsuddannelsen - med følgende fordeling: 11 undervisere fra pædagoguddannelsen, 7 fra sygeplejerskeuddannelsen, 4 fra socialrådgiveruddannelsen og 2 fra ernæring- og sundhedsuddannelsen, i alt 24 personer samt 4 projektgruppemedlemmer, 1 fra hver uddannelse. Nogle af underviserne, ca. ${ }^{1 / 4}$, var helt nye eller ret nye på e-læring, mens ca. $1 / 6$ havde været på e-læring i adskillige år. Alle undervisere var tildelt 102 timer til kompetenceudviklingsforløbet, der blev afviklet efterår 2018.

Forløbet var tilrettelagt som en spejling af de studerendes undervisningsforløb med en vekslen mellem virtuelle uger og f2f-fremmøde, organiseret i to moduler: 1 . modul: 1 virtuel uge - 1 dags f2f - 2 virtuelle uger - 1 dags f2f - 6 virtuelle uger -1 dags f2f (slut på 1. modul og start på andet) - 3 virtuelle uger - 1 dags f2f - 3 virtuelle uger -1 dags f2f.

I de følgende afsnit præsenteres forløbet, som det var planlagt, hvorefter afsnittene med nedslag på afvikling følger.

\section{Forløbets bærende principper}

På baggrund af forløbets forankring i pragmatismen og DBR samt de forudgående undersøgelser, herunder undervisernes ønsker, var forløbet tilrettelagt ud fra nogle gennemgående principper (Cherryholmes, 1999; Wang \& Hannafin, 2005). Det første princip var, at e-didaktik og teknologi skulle gå hånd i hånd. Konkret betød dette, at deltagerne på et teoretisk informeret e-didaktisk grundlag og med teknologi-assistance af to omgange - én gang i hvert modul - skulle designe små-forløb/opgaver, som skulle afprøves på virkelige e-studerende. "At designe” er her defineret som en proces, en række handlinger, og når der i det efterfølgende står "et/flere design”, er der tale om undervisernes færdige 
"produkter" (jf. Dohn \& Hansen, 2016). På baggrund af eksperimenterne skulle underviserne være med til at afprøve og udvikle en design-"skabelon" (uddybes nedenfor). I forbindelse med første princip kan nævnes, at forløbet søgte at udmønte et syn på teknologi, hvor der var fokus på inddragelse og brug af teknologier, men at teknologierne ikke blev set som de primære aktører, men at de indgår i en proces, hvor undervisere og teknologier tilsammen skaber undervisningen og mulighederne ift. studerendes læringsudbytte (jf. Amiel \& Reeves, 2008). Denne forståelse og den teknologiforståelse, som den implicerer, er af Jørnø og Gynther (2018) formuleret, som at teknologi ikke determinerer, men at valget af teknologi skaber bindinger, der giver mulighed for nogle udfaldsrum og udelukker andre, hvorfor de taler om socio/tekniske konstellationer som betegnelse for, hvordan givne undervisere agerer med valgt teknologi. Dette samspil søgte projektet at sætte i centrum ved at fokusere på (e)-didaktik og teknologi som sammenvævede, gensidigt afhængige størrelser.

Et andet princip var, at underviserne skulle være relevant aktive. Deres eksperimenter skulle tage udgangspunkt i reelt oplevede/eksisterende udfordringer og opgaver i e-læringsundervisernes daglige praksis. Dvs. at deres udgangspunkt var problembaseret (jf. Garrison, 2016). Dette princip var med henblik på at styrke motivationen og sikre, at eksperimenterne ville blive en del af undervisernes praksis fremover i modsætning til udefra styrede tiltag, der opleves uvedkommende for deltagerne. Sidstnævnte er desværre udbredte oplevelser af de kurser/kompetenceudvikling, som undervisere ofte ufrivilligt bliver allokeret til. Ud over motivationen gav dette princip også mulighed for, at alle undervisere oplevede et udbytte af eksperimenterne - undervisningsdifferentiering - idet enhver tog udgangspunkt i eget niveau og eksperimenterede der fra. Indeholdt i dette princip var endvidere, at deltagerne skulle være aktive både ift. at tænke e-didaktisk og udføre tænkningen i praksis som to sider af samme sag, jf. DBRs grundlag i pragmatismen (Wang \& Hannafin, 2005).

Yderligere en konsekvens ift. "deltagerne som aktive" og det faktum at en del af de deltagende undervisere havde lang erfaring som e-undervisere var, at f2f dagene også skulle give mulighed for diskussioner, refleksioner og udvekslinger på tværs af uddannelserne. Her er det grundlæggende Deweys pointe om fællesskabets betydning ift. problemløsning (Brinkman, 2006; Dewey \& Dewey, 1915), vi udmøntede.

Et tredje princip var, at forløbet skulle være eksemplarisk ift. deltagernes egen praksis (Dewey, 1908). Dette havde konsekvenser for to niveauer: For det første ift. kursets overordnede udformning som et elæringsforløb hvor deltagerne var i "studerende"-position og dermed (også) kunne opnå indsigt i deltagerpositionen. Det betød, at de to moduler var tilrettelagt som blended undervisning - de i alt 5 f2f dage og 15 virtuelle uger (jf. ovenfor). For det andet skulle præsentationsniveauet (Dohn \& Hansen, 2016), kursets frontersider, være eksemplarisk udformet mhp. at inspirere deltagerne ift. deres egen praksis - både ift. forløbs- og opgavebeskrivelse samt anvendelse af teknologier/programmer. De to nævnte elementer var tænkt ind som konsekvens af pragmatismens fordring om vedvarende problematisering af egen praksis og afvisning af endegyldige sandheder (Dazzani, 2005).

\section{Forløbets platform}

Forløbets platform var Fronter, for at også præsentationsniveauet kunne være eksemplarisk ift. undervisernes egen praksis. Dette gjaldt struktur, formuleringer, redskaber mv. der skulle kunne inspirere deltagerne direkte ift. deres egen praksis. Fronterrummet var forud for hvert modul færdiggjort, hvilket var en bestræbelse på - igen mhp. at være eksemplarisk ift. forløb med studerende at give deltagerne mulighed for overblik over det forestående forløb. Fronterrummet havde en start-side med overordnede informationer og to undersider, en for hvert modul, organiseret efter ens principper. Mhp. det eksemplariske blev der lagt vægt på overensstemmelse mellem de e-didaktiske elementer, der var tænkt inddraget i fx oplæg og dem, der blev benyttet ift. opgaveformuleringer til underviserne, altså ift. deres eksperimenter. Dette gjaldt fx Gilly Salmons opgaveintro (Salmon, 2013), som underviserne fik præsenteret som en mulig fælles opgaveintro ift. studerende. 
Derudover blev der på platformen benyttet diverse redskaber mhp. at inspirere underviserne: Videoer: Talking head, modultrailer, speeddrawing, interaktiv video, oplægsvideo og info-video om bla. ABCmodellen. Derudover diverse programmer: Thinklink (billeder med indtalt lyd), Easelly (virtuel planche), fronter-afstemning, tegneserie-program, Wordart (ordsky) og Padlet (virtuel opslagstavle). Yammer var gennemgående kommunikationsplatform, og på modul 2 skulle Peergrade (program til at give og modtage feedback) benyttes til aflevering og feedback.

\section{F2F-dagene}

Forløbet var planlagt, så f2f-dagene i begyndelsen og slutningen af hvert modul indeholdt oplæg om didaktik, e-didaktik og nyere forskning med tilhørende diskussioner/refleksioner (det teoretiske aspekt uddybes nedenfor). Projektgruppen havde på forhånd sammensat grupper på tværs af uddannelserne, mhp. at disse grupper skulle fungere både som diskussionsgrupper på f2f-dagene og som sparringsgrupper i de virtuelle uger. Sammensætningen på tværs af uddannelser var et meget bevidst valg baseret på forestillingen om, at møder mellem naturvidenskabeligt, humanistisk og samfundsfagligt funderede undervisere kunne være gensidigt inspirerende (Garrison, 2016; Wang \& Hannafin, 2005). Det var derfor en fordel, at netop pædagoguddannelsen deltog med så mange undervisere i forhold til sygeplejerske- og ernærings- \& sundhedsuddannelsen, så der var en balance mellem naturvidenskab og humaniora, mens de få deltagere fra socialrådgiveruddannelsen gjorde samfundsfag underrepræsenteret. Helt basalt efterkom enhver form for blanding undervisernes ønsker om inspiration uden for egen uddannelse. Hensigten var, at underviserne i grupperne skulle give hinanden feedback på de udviklede design og problematisere hinandens praksis og derved i tråd med pragmatismens tilgang i fællesskab kvalificere designene (jf. ovenfor).

Den midterste f2f-dag på hvert modul var planlagt som en teknologiworkshop, således at der også skete en opkvalificering på teknologisiden. Disse workshops - én i hvert modul - var et samarbejde med organisationens it-afdeling, Digital. Normalt kommer folk fra Digital ud på uddannelserne og underviser $i$ et på forhånd udpeget program/redskab, som alle deltagere på den givne uddannelse så modtager undervisning $i$, uanset om de har et behov for netop dette redskab eller ej. I dette tilfælde, hvor hver enkelt underviser skulle arbejde med noget, der var specifikt relevant for hende/ham, duede itafdelingens normale koncept ikke, og samarbejdet blev derfor også for Digital et udviklingsforum. Formatet blev, at projektgruppen forud for hver workshop lavede et teknologi-arbejds-ønske-dokument, som undervisere udfyldte inden workshoppen, hvorefter projektgruppe og en repræsentant for Digital inddelte ønsker i passende workshops-temaer. På selve dagene kunne deltagerne derefter efter eget ønske placere og omplacere sig i de forskellige tilbud og fă hjælp af personer fra Digital. Digital var repræsenteret med ca. 3 personer pr gang. Eksempler på workshops: "Video \& lyd", "Explain Everything, quizzer \& Prezi", "Peergrade". Underviserne var opfordret til på forhånd at afprøve teknologierne mhp. at identificere udfordringer og dermed få det største udbytte af Digitals tilstedeværelse.

Den sidste f2f-dag på hvert modul var planlagt med fremlæggelser af de eksperimenter, som underviserne enkeltvis havde arbejdet med. Formålet hermed var gensidig inspiration, og grupperne skulle derfor være i nogle andre grupper end de grupper, underviserne havde været i undervejs i modulet.

Slutteligt var forløbet også planlagt med evalueringer - en formativ mundtlig evaluering efter modul 1 og en summativ skriftlig evaluering ift. både modul 1 og 2 efter 2. modul.

\section{Kompetenceudviklingsforløbets teoretiske indhold}

Som nævnt i afsnittet "Udviklingsprojektets teori og metode" var den teoretiske ramme på kompetenceudviklingsforløbet Community of Inquiry (CoI) (Garrison, 2016). Som indledning til CoI indeholdt første f2f en gennemgang af bl.a. begreberne "didaktik", "læring”, "design" og 
"præsentationsniveau". Herunder en generel tilnærmelse til at tænke didaktisk og e-didaktisk med bla. Laurillard (2012) og en sondring mellem den angelsaksiske og den kontinentale forståelse af didaktik (Dohn \& Hansen, 2016), og formålet var igen, dels at problematisere deltagernes bestående opfattelse og praksisser, dels at etablere en fælles begrebsramme. CoI, som efterfølgende var den e-didaktiske ramme, rummer med sin forankring i pragmatismen en intention om tilbagevendende refleksion hos deltagerne (underviser og underviste) over den lærendes engagement ift. læringsindholdet, og over mulighederne for at den lærende (også virtuelt) socialt kan deltage på en ift. sin person mangefacetteret måde. CoI-modellens tredje hoveddimension angår og lægger op til refleksion over den måde, underviseren balancerer det indholdsmæssige engagement og det sociale element samt over, hvor klart designet i et givent forløb er - det hele ift. den intention der er med undervisningsforløbet (Garrison, Anderson \& Archer, 1999).

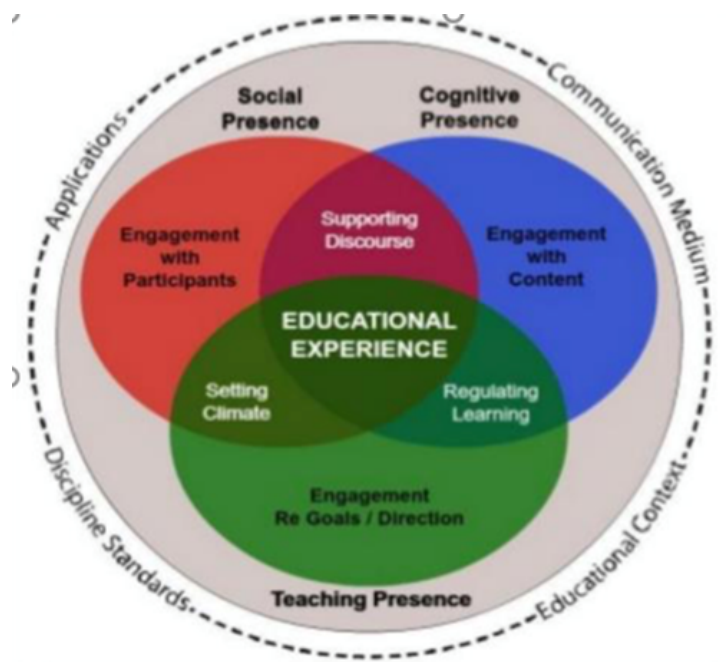

(Figur 1. CoI-modellen. Garrison, 2016, s. 59)

CoI-modellen er ikke en planlægningsmodel, men en analysemodel. Projektgruppen havde i planlægningen af forløbet derfor en del diskussioner, vedrørende hvorvidt CoI-modellen i sig selv ville blive oplevet som tilstrækkelig for alle underviserne, når de selv skulle udvikle design. Projektgruppen bestod som nævnt af én fra hver af de deltagende uddannelser, og allerede i de indledende faser af projektet var det klart, at deltagerne kom fra uddannelser med vidt forskellig indsigt i didaktik. På fx pædagoguddannelsen undervises de studerende i didaktik, og underviserne er således inde i emnet, mens didaktik ikke er en del af undervisningen på fx ernærings- og sundhedsuddannelserne. Underviserne i almindelighed fra fx denne uddannelse kunne dermed tænkes ikke at have et meget dybtgående kendskab til didaktik, men måske have et mere rent praktisk tilrettelæggelsesfokus foranlediget af egne udfordringer med at tilrettelægge undervisning. Resultatet af projektgruppens overvejelser blev, at gruppen ud fra CoI-modellen - og i en samtænkning med ABC-modellen (Laurillard, 2016), som har et redskabsfokus - lavede en design-"skabelon” bestående af en række spørgsmål, som underviserne i deres designproces kunne stille sig selv og i grupperne hinanden, i og med de samme spørgsmål indgik i en udarbejdet feedback-skabelon. Når der ikke bare blev inddraget en anden edidaktik-model, var det, fordi ingen af dem, gruppen undersøgte, kunne matche CoI-modellen, når det gjaldt om at favne hele e-didaktikken.

Modellen ses her i sin første udgave, ved starten på forløbet: 
Tabel 1. Designskabelon.

\begin{tabular}{|l|l|}
\hline Tema & \\
\hline Hvad skal de studerende lære? (Cognitive presence) & \\
\hline Hvilke aktiviteter/læringstyper er der overordnet set fokus på? (Cognitive presence) & \\
\hline $\begin{array}{l}\text { Hvilke læringstyper har du fokus på? (Cognitive presence) Her detaljeret: } \\
\checkmark \\
\text { Diskussion } \checkmark \text { Samarbejde } \checkmark \text { Undersøgelse } \checkmark \text { Øvelse } \checkmark \text { Individuel videnstilegnelse } \\
\text { Seks læringstyper som kommer fra ABC-modellen, hvor også teknologier kobles på. }\end{array}$ & \\
\hline Hvordan skal de studerende samarbejde? (social presence) & \\
\hline Hvordan sørger jeg som underviser for, at jeg opleves til stede? (Social presence) & \\
\hline Hvilken teknologi understøtter de studerendes læreprocesser (herunder de specifikke læringstyper)? & \\
\hline Hvilken teknologi støtter underviserformidling? & \\
\hline Hvilket digitalt produkt vidner om deltagelsen? & \\
\hline Hvornår afvikles designet, og hvor lang tid strækker det sig over? & \\
\hline Designet beskrives, så det kan forstås af studerende (Teaching presence) & \\
\hline
\end{tabular}

Oplægget til deltagerne var, at disse design-spørgsmål var den fælles ramme, som design- og feedbackprocesserne skulle foregå i, men at hensigten var, at alle underviserne i fællesskab skulle udvikle "skabelonen", og at den derfor ville blive evalueret og revideret i slutningen af hvert modul. Enhver skulle derfor undervejs i sin designproces være opmærksom på, hvorvidt spørgsmålsrækken var dækkende ift. at bedrive blended learning. Indlejret i forløbet var således, at deltagerne var medudviklere af en didaktisk model, og planen var, at en sådan model senere kunne udbredes til alle elæringsundervisere i Absalon.

Udover ovennævnte teoretiske elementer indeholdt 2. modul et fokus på teaching presence (CoImodellen) og altså selve tilrettelæggelsen med balanceringen af det indholdsmæssige og det sociale engagement, og her indgik inddragelse af, hvad nyere forskning kunne sige i relation hertil. Eksempler herpå er spørgsmålet om, hvorvidt underviseren skal inkorporere synkrone eller asynkrone diskussioner i sit design (Watts, 2016) og betydningen af teacher presence samt social presence (Zilka, Cohen \& Rahimi, 2018).

\section{Afvikling \& erfaringer}

Dette afsnit indeholder nedslag på selve afviklingen af forløbet. Der er således tale om udvalgte elementer, ud fra hvad der undervejs og efter forløbet har givet anledning til størst forundring og/eller refleksion i projektgruppen. Indledningsvis kan det dog konstateres, at afviklingen ikke alene i hovedtræk, men også langt ned i detaljerne kom til at forløbe som planlagt jf. ovenfor. Der var således ikke brug for radikale planlægningsmæssige ændringer undervejs, men kun mindre justeringer og tilføjelser. Disse justeringer vil blive nævnt i det følgende, da de netop måtte foretages i forlængelse af noget, der skabte undren.

\section{Tværprofessionelt regi med divergerende læringsforståelser}

Deltagerne i kompetenceudviklingsforløbet kom som nævnt fra forskellige uddannelser og uddannelsessteder og repræsenterede hermed forskellige professionsidentiteter, samtidig med at der inden for samme profession var deltagere med forskellig faglighed. Denne diversitet af deltagere skabte gode muligheder for dialog via CoI-tænkningen (Garrison, 2016), samtidig med at det også motiverede 
deltagere til at udvikle evnen til at anskue egne handlinger med andres øjne (Mead, 1934). Eksempelvis havde en gruppe undervisere på et uddannelsessted et ønske om at producere mange videoer, hvor andre deltagere mente, at læring medieret gennem videoer hæmmede dialogen. Disse forskellige forståelser gav anledning til refleksioner over læringstilgange og over, hvorvidt studerende på tværs og inden for samme profession burde mødes ens eller forskelligt i sådanne spørgsmål. Læringsteoretiske og didaktiske dialoger var tidsmæssigt og indholdsmæssigt planlagt undervejs i forløbet, men blev samtidig også udfoldet af deltagerne på tidspunkter, der havde mere teknologisk karakter i kompetenceudviklingsforløbet. Der blev derfor fra projektgruppens side justeret lidt på nogle af de tidsmæssige rammer, sådan at ikke planlagte indholdsmæssige temaer også kunne berøres.

Et andet tema der blev tydeligt undervejs i kompetenceudviklingsforløbet var, at nogle af deltagerne bevidst, og for nogle, ubevidst, bekendte sig til en form for behavioristisk læringsforståelse (Skinner, 1971), hvor læring bliver anset som videregivelse af indsigt og som en individuel tilegnelsesproces med forskellige ydre motivationelle virkemidler i form af straf eller belønning. Denne læringsforståelse blev for nogle af deltagerne opfattet som en opposition til læringsforståelsen, der blev præsenteret via CoImodellen, og modsætningen blev opfattet som en reducerende faktor ift. metodefriheden i kompetenceudviklingsprojektet. Projektgruppen havde via DBR-metoden og CoI-modellen præget deltagerne med en vej og læringsforståelse om konstruktion, kollaboration og dialog, "thinking collaboratively simply outperforms that of the individual" (Garrison 2016, s. 18), hvilket mindskede muligheden for nogle af deltagernes ønske om at tilrettelægge individuelle og autoritativt styrede læringsforløb. Empirien fra startfasen i projektet viste et ønske om opkvalificering inden for bl.a. edidaktik, og var fra deltagernes side ikke nærmere defineret i forhold til læringsteoretiske positioner. Projektgruppens tilgang til e-didaktik var jf. ovenfor funderet i etableret pragmatisk forskning (Garrison, 2016), men erfaringerne fra kompetenceudviklingsforløbet viser, at ikke alle deltagere var enige i den teoretiske ramme for forløbet. En struktur med mulighed for tidsmæssige justeringer til oppositionelle dialoger om rammen blev opfattet som hensigtsmæssigt af nogle af underviserne, og disse dialoger fik derfor plads i forløbet i overensstemmelse med pragmatismens problematiseringsfokus (Cherryholmes, 2013; Dewey \& Dewey, 1915).

I CoI-modellen influeres den læring, der måtte finde sted, af den gruppe, der deltager, "The group provides the means to select the best ideas and actions that serve all members." (Garrison 2016, s 18). Kompetenceudviklingsforløbet viste, at deltagerne i gruppen besad erfaringer og ræsonnementer, ift. hvad de selv finder hensigtsmæssigt $\mathrm{i}$ relation til at tilrettelægge og afholde blendede undervisningsforløb. Et opmærksomhedspunkt i relation til læring og tænkning i kollaborationer er, at fundamentalistiske holdninger til blended learning kan forekomme - det at en deltager udvælger ytringer og forudser handlemuligheder, som det selverklæret er enig i, jf. sit eget ræsonnement. Erfaringerne fra kompetenceudviklingsforløbet viste, at det ikke umiddelbart var muligt inden for alle områder, at gruppen kunne udvikle en villighed til at sætte spørgsmålstegn og kritisere med henblik på at finde nye idéer og derved komme væk fra handlinger, der forsvarede eksisterende mønstre og strukturer. Pragmatismen tilstræber en antifundamentalistisk tilgang, ift. at vi i en ikke-statisk verden kontinuerligt forsøger at sætte spørgsmålstegn ved etablerede handlinger og erfaringer (Cherryholmes 1999). Intentionen var i kompetenceudviklingsforløbet at få udviklet et gruppesamarbejde med åben dialog og en gruppeidentitet med lyst til at forholde sig udforskende og nysgerrig til problemer efter CoIprincipperne (Garrison, 2016). Dette blev, paradoksalt nok, opfattet af nogle af deltagere som en dominerende og begrænsende forudbestemt struktur. Den deweyanske læringstænkning, "Give freedom to find out what he can and can not do, what is possible and what his neighbors will stand for" (Dewey \& Dewey, 1915, s. 139), blev forsøgt operationaliseret via CoI-modellen, men erfaringerne viste, at det ikke altid lykkedes inden for alle emner og problemområder, samtidig med at nogle af deltagerne altså også opfattede selve CoI-modellen som en fundamentalistisk ramme, der begrænsede visse handlinger.

En anden grundlæggende overbevisning, som det viste sig svært at udfordre, var holdningen til, hvorvidt det er ønskeligt, at de studerende har mulighed for - og der lægges op til - at gennemføre undervisningen uden overhovedet at møde frem, selv om det er blended learning. Nogle undervisere mente, at dette var 
fint ift. studerende med fx angstproblematikker el. lign., mens andre mente, at fremmøde og det at kunne interagere med andre $\mathrm{i}$ et fysisk rum er en vigtig del af den personlige dannelsesproces $\mathrm{i}$ uddannelser, der uddanner til at have med mennesker at gøre.

\section{Tværprofessionelle diskussioner af design-skabelonen}

Den planlagte vekslen mellem teori (e-didaktik) og praktiske teknologiske færdigheder var i sig selv en vældig succes målt på deltagernes udsagn undervejs og i den afsluttende evaluering. Den planlagte udvikling af design-"skabelonen" gav anledning til spændende didaktik-diskussioner i slutningen af hvert modul. Efter første modul blev det således problematiseret, at spørgsmålsrækken ikke indbefattede, "hvorfor underviseren ville undervise i det givne indhold", hvilket af nogle blev set som en absolut grundlæggende og nødvendig refleksion i forbindelse med enhver undervisning. Andre anså "hvorfor"-dimensionen for at være totalt ligegyldig og spild af tid. Alle ytrede sig ikke om spørgsmålet, men det var tydeligt, at de afvisende kom fra de naturvidenskabeligt funderede uddannelser, og man kan have den hypotese, at en forankring i et videnskabsområde, hvis indhold fremstår som ubetvivlelig viden, har påvirket underviserne til heller ikke at være problematiserende, når det gælder hendes/hans egen indholdsudvælgelse. Fortalerne for at have "hvorfor"-dimensionen med kom fra pædagoguddannelsen, og diskussionen var således et eksempel på forskellige underviserholdninger på de forskellige uddannelser. Det er ikke sandsynligt, at nogen ligefrem ændrede holdning, men intensiteten i diskussionen tydede på, at det var overraskende - og nyt - for deltagerne, at opfattelserne kunne være så divergerende. De i foregående afsnit refererede forskellige læringssyn kunne meget vel tænkes at have samme forankring.

Et andet element, der blev taget op i forbindelse med udviklingen af design-"skabelonen", var betydningen af rummenes affordances, hvor rum både kunne være fysiske og virtuelle. Undervisere med musisk-kreative fag påpegede, at nogle ting - øvelser - ikke kunne udføres virtuelt eller i hvert fald ikke med samme kvalitet som i det fysiske rum. Dermed blev deltagernes opmærksomhed henledt på fagenes (også inden for uddannelserne) forskellighed og de udfordringer, som nogle undervisere står med, når undervisning gøres blended med overvægt af virtuelle perioder.

Andre kommentarer ift. "skabelonen" gik på, at den ikke grafisk fremstod processuel. Undervisere, der ikke var vant til at arbejde med didaktikmodeller, havde oplevet at arbejde sig igennem spørgsmålene for efterfølgende at ændre et af deres svar og så blive opmærksom på, at ændring ét sted nødvendiggjorde ændringer i flere svar og dermed i deres design. Disse underviseres erkendelse var overraskende for undervisere, der er vant til forskellige didaktikmodeller, der som regel altid indeholder, at de enkelte elementer påvirker hinanden (fx Hiim \& Hippes didaktiske relationsmodel (Hiim \& Hippe, 2002), Broströms kontekstuelle og situationsbestemte didaktiske model (Bröstrøm, 2017) og Smttemodellen (EMU)).

På baggrund af deltagernes kommentarer blev "skabelonen" efter første modul revideret og fik nedenstående fremtræden. Denne udgave blev evalueret efter 2. modul, men her havde ingen revisionsforslag. Til gengæld var der kommentarer spændende meget vidt i forhold til overhovedet at bruge en så struktureret fremgangsmåde i sin undervisningstilrettelæggelse. Nogle undervisere tilkendegav, at det havde været en gave til deres planlægning; her var tale om nogle, der ikke tidligere havde arbejdet struktureret med didaktik. Andre mente, det var for tidskrævende decideret at skulle udfylde en sådan model, men anså spørgsmålene for at være gode at have i baghovedet under planlægningen. Generelt var der enighed om, at det havde været udbytterigt at have en fælles ramme at diskutere design ud fra. 


\begin{tabular}{|c|c|c|}
\hline & Tema & \\
\hline$\nabla$ & Hvad skal de studerende lære? (Cognitive presence) & \\
\hline $\mathbf{t}$ & Hvorfor skal de lære dette? (Teaching presence) & \\
\hline $\boldsymbol{\downarrow}$ & $\begin{array}{l}\text { "Hvordan" - hvilke aktiviteter/læringstyper er der fokus på?? (Cognitive presence) Beskriv } \\
\text { aktiviteterne overordnet. }\end{array}$ & 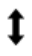 \\
\hline$\downarrow$ & $\begin{array}{l}\text { Hvilke læringstyper har jeg fokus på? (Cognitive presence) } \\
\checkmark \text { Diskussion, } \sqrt{ } \text { Samarbejde, } \sqrt{ } \text { Undersøgelse } \\
\checkmark \checkmark \text { Øvelse, } \sqrt{ } \text { Individuel videnstilegnelse, } \sqrt{ } \text { Produktion }\end{array}$ & \\
\hline $\mathbf{t}$ & Hvordan skal de samarbejde? (social presence) & \\
\hline$\downarrow$ & $\begin{array}{l}\text { Hvordan sørger jeg som underviser for, at jeg opleves til stede? (Teacher presence - del af } \\
\text { Social presence) }\end{array}$ & 1 \\
\hline $\boldsymbol{t}$ & $\begin{array}{l}\text { Hvilken teknologi understøtter de studerendes læreprocesser (herunder de specifikke } \\
\text { læringstyper)? }\end{array}$ & 1 \\
\hline $\mathbf{t}$ & Hvilken teknologi støtter underviserformidling? & 1 \\
\hline $\boldsymbol{1}$ & Hvilket digitalt produkt vidner om deltagelsen? & \\
\hline $\mathbf{t}$ & Hvornår afvikles mit design, og hvor lang tid strækker det sig over? & 1 \\
\hline $\mathbf{t}$ & $\begin{array}{l}\text { Hvilken feedbackmængde - og fra hvem - skal de studerende have og i hvilket format (skrf? } \\
\text { video? peergrade? x?) }\end{array}$ & 1 \\
\hline \multirow[t]{3}{*}{ 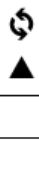 } & $\begin{array}{l}\text { OG så den vigtigste: Beskriv designet for en studerende, så det kan forstås af denne og af } \\
\text { en kollega. (Teaching presence) } \\
\text { Gør dette ved at udfylde Opgaveintroen nedenfor }\end{array}$ & 乌 \\
\hline & Er der tekniske beqrænsninqer, jeq skal være opmærksom på? & \\
\hline & $\begin{array}{l}\text { Burde der være tilknyttede praktisk-musiske/æestetiske eller sociale aktiviteter, men som } \\
\text { ikke er mulige virtuelt, og som skal placeres } \mathrm{f}_{2} \text { ? }\end{array}$ & \\
\hline
\end{tabular}

Figur 2. Revideret design-skabelon

\section{Teknologikompetencerne}

Det var for projektgruppen glædeligt - og også lidt overraskende - at opleve, hvorledes underviserne på tværs af uddannelserne blev inspireret af hinandens anvendelse af redskaber. Som eksempel kan nævnes, at én fra projektgruppen til projektets fronterside havde udarbejdet en speed-drawing-video med projektinfo. Denne video bevirkede, at der til den 2. teknologiworkshop blev ønsket en workshop, hvor man lærte at lave den slags videoer. En af medarbejderne fra Digital lavede selv et lille eksempel på speeddrawing, som han tog udgangspunkt i i instruktionen i sin workshop. Derefter sad nogle undervisere fra både pædagog-, socialrådgiver- og sygeplejerskeuddannelsen og udarbejdede/påbegyndte hver deres speeddrawing-video, mens de udvekslede ideer og tekniske fif.

Workshop-formatet lagde op til, at man hjalp hinanden, idet det jo heller ikke var muligt for tre Digitalfolk at hjælpe alle på én gang. Dette betød også, at der i nogle tilfælde var tale om, at nogle få deltagere sad forholdsvis "alene" og med et redskab, som de udvekslede omkring og kun i mindre grad havde adgang til Digitalfolkene.

Oplægget fra projektgruppen var, at enhver skulle afprøve et for personen nyt redskab, som hun/han på forhånd havde fået kendskab til som (evt.) relevant ift. det design, hun/han var i gang med. Kendskabet kunne fx være fra de andre i den gruppe, man var organiseret $i$, det kunne være inspiration fra projektsiden, eller det kunne være et redskab, som personen i gennem længere tid havde haft i kikkerten.

Som nævnt var tilfredsheden med kombinationen af e-didaktik og teknologi stor. Især var alle yderst tilfredse med teknologidelen - nogle undervisere havde på forhånd et godt didaktikkendskab og blev 
dermed ikke så opkvalificeret som andre uden kendskab, mens alle i forhold til teknologidelen blev opkvalificeret, idet man arbejdede i forlængelse af eget aktuelle niveau.

\section{Samarbejdet i grupperne}

Underviserne skulle i forløbet arbejde i grupper for i tråd med pragmatisme-tilgangen at kvalificere deres individuelle design og afprøvninger, og for at forløbet skulle være eksemplarisk ift. undervisernes egen praksis. Denne organisering bød set fra projektgruppens side på generelt gode elementer, men også nogle overraskende, mindre gode.

Som eksempel på førstnævnte var diskussionerne på faf-dagene, hvor underviserne fra første dag var placeret i de på forhånd inddelte tværgående grupper. Der var ivrige diskussioner, hvor alle øjensynligt havde lyst til at bidrage samt høre på andre og accepterede at følge projektgruppens til tider ret stramme struktur. Der syntes også at være en åbenhed omkring diverse udfordringer i e-læringsarbejdet med de studerende og en vilje til også at dele mindre gode undervisningserfaringer.

Yderligere et eksempel på førstnævnte var nogle af tilbagemeldingerne fra gruppearbejdet ift. at gruppesammensætningen på tværs af uddannelser havde været indholdsmæssig udbytterig, fordi man derved blev bekendt med andre måder at forstå undervisning på. Til trods for at "de andre" underviste i et andet indhold, kunne underviserne godt give metodisk feedback og herunder rådgive hinanden om programmer/redskaber. Her fik deltagerne et kig ind i andre verdener og tilkendegav, at de både var blevet beriget og i nogle tilfælde udfordret på egne "sandheder".

På den anden side var det undervejs for projektgruppen en overraskelse, at det var en udfordring for (nogle af) de deltagende undervisere at få gruppearbejdet til at fungere i de virtuelle perioder. Som nævnt skulle underviserne som del af kvalificeringen af hver enkelts design mødes online og give hinanden feedback to gange i det første modul og én gang i det andet modul. I det 2. modul var den ene feedbackdel henlagt til Peergrade, for at dette også kunne blive en erfaring for deltagerne. Overraskelsen indtraf allerede mellem første og anden f2f og på anden f2f, hvor flere af underviserne henvendte sig til projektgruppen og beklagede sig over, at det var svært at fă aftalt et virtuelt møde med de øvrige i gruppen. Der var kommentarer som "Nu har jeg prøvet to gange, men så er én syg, og en anden svarer ikke, og den tredje har meget travlt, så nu vil jeg altså ikke mere være den, der forsøger” - sagt på en måde, der viste, at underviseren godt kunne høre, at det var en præcis gengivelse af det, vi møder i undervisningen med studerende. De andre henvendelser var af lignende karakter, og gruppearbejdet blev også problematiseret i plenum. Nogle grupper fungerede upåklageligt og havde haft fornøjelse af samarbejdet, og i andre grupper var det lykkedes for tre ud af fire at holde møde, hvilket blev oplevet som okay af gruppen.

Når det var overraskende for projektgruppen, at gruppesamarbejdet bød på udfordringer, var det, fordi alle undervisere uden undtagelse bedriver undervisning med studerende, hvori gruppearbejde er en væsentlig faktor. Vi havde derfor formodet, at underviserne ville acceptere og prioritere gruppedelen mhp. at opfylde forpligtelserne i forløbet - som de jo var tildelt ca. 100 timer til.

For at forebygge at lignende problemer skulle opstå i modul 2 indlagde projektgruppen på modul 2s første dag 45 minutter, hvor gruppedeltagerne i de nye grupper - grupperne skiftede fra modul 1 til 2 ud fra en række spørgsmål skulle aftale, hvornår de ville afholde møder, hvem der havde ansvaret for at kontakte de fraværende mm. Dette tiltag bevirkede øjensynligt, at der var færre frustrationer i modul 2 - såfremt der var frustrationer, kom de i hvert fald ikke til projektgruppens kendskab.

Projektgruppen reflekterede efterfølgende over den umådelige lighed mellem at afholde kompetenceudvikling for kolleger og undervise studerende. De samme forhold og mekanismer, som vi på daglig basis møder med de studerende, mødte vi i forløbet med vores kolleger. Denne iagttagelse - 
som underviserne også gjorde - blev en væsentlig del af de metarefleksioner, som blev en vigtig del af forløbet, og som er omdrejningspunktet i næste afsnit.

\section{Metarefleksioner som et væsentligt punkt}

CoI-modellen som ramme tilstræber en "shared metacognitive process" (Garrison, 2016, s. 23), det at kunne kommunikere, forklare og argumentere ens handlinger til en selv og andre i gruppen. Denne delte metakognitive proces betød, dels at deltagerne indbyrdes fik indblik i hinandens tanker, samtidig med at vi i projektgruppen også fik et indblik. I den forbindelse blev vi opmærksomme på det, som vi her vil kalde metarefleksioner, som defineres som: "A form of mental processing with a purpose and/or anticipated outcome that is applied to relatively complex or unstructured ideas for which there is not an obvious solution" (Moon, 1999, s. 23), og hvor metarefleksion opfattes som en refleksion over refleksioner. Underviserne blev i kompetenceudviklingsforløbet udsat for et miljø, der mindede om det, som de studerende møder, jf. intentionen om forløbet som eksemplarisk. Som omtalt ovenfor, oplevede nogle grupper udfordringer med at kunne koordinere og arbejde sammen, hvor dele af arbejdsopgaverne ikke blev udført. Dette blev italesat af nogle af deltagerne som et element, de også oplevede med deres egne studerende, hvilket medførte en refleksion over, om problemet er de studerendes evner og vilje til at interagere med indholdet, eller om det er den struktur, som planlæggeren rammesætter, der er problemet. Denne metarefleksion var en blandt flere, der blev opfattet som en ikke-planlagt 'aha-oplevelse' for projektgruppen, men som efterfølgende er blevet opfattet som et særdeles vigtigt læringselement for kompetenceudviklingens deltagere. Nedenfor vil nogle af metarefleksionerne blive fremhævet for på den måde at give indblik i nogle af de utilsigtede konsekvenser, som forløbet også medførte, og som giver en indikation af vigtigheden af, at kompetenceudviklingsdeltagere får lov til at blive sat i en position, hvor de selv får lov til at opleve det, som deres studerende oplever.

Underviserne skulle jf. ovenfor i forløbet anvende Fronter som stedet, hvor beskrivelser, videoer og øvelser var placeret af projektgruppen. Her oplevede vi, at nogle af deltagerne havde svært ved at finde dele af indholdet, da logikken i vores opbygning ikke var lige så tydelig for underviserne, som den var for projektgruppen. En tilbagevendende metarefleksion var, at underviserne i opbygningen af LMS-rum måske også selv kommer til at opbygge en indforstået logik over flere uger i planlægningsfasen, og som er tydelig for dem, men som kan fremstå uklar for studerende. På forløbets første dag, hvor nogle (uforberedte) undervisere for første gang skulle finde rundt i Fronterrummet, udspillede sig nogle - for projektgruppen - komiske scener, hvor nogle undervisere ikke kunne finde rundt i rummet og informationerne og så med små-panisk stemme krævede øjeblikkelig hjælp. Situationen var meget lig situationer med studerende.

Et andet fokusområde der var blevet problematiseret af underviserne i Absalon-Es empirifase var, at de oplever, at studerende ikke altid deltager i aktiviteter som skypemøder, online læringsøvelser eller nogle gange bliver væk fra fysisk undervisning. Dette aspekt viste sig også at være aktuelt for underviserne i kompetenceudviklingsforløbet, der ikke i alle henseender, formåede at løse de arbejdsopgaver, der var blevet rammesat. Eksempelvis fik kun 12 ud af 24 deltagere løst en padlet-arbejdsopgave med at formulere, hvilken teknologi de havde arbejdet med til teknologiworkshoppen. Da vi efterfølgende havde en fælles dialog om, hvorfor denne øvelse ikke var blevet gennemført af alle, bemærkede en af deltagerne, at de ytringer, der kom ("Havde ikke hørt at det skulle laves", "Var syg", "Kunne ikke finde ud af det", "Havde glemt det", "Havde travlt med andre arbejdsopgaver"), mindede om dem, som studerende også kom med i personens undervisningsrum.

Et tredje element var, at på trods af at kompetenceudviklingsforløbet var struktureret ud fra deltagernes egne ønsker om fokus på blandt andet e-didaktik og teknologi, var alle deltagere ikke lige forberedte eller motiverede for at interagere med indholdet. Det kom blandt andet til udtryk ved, at nogle deltagere 
lavede andre ting, mens kompetenceudviklingen stod på, som fx. at skrive mails eller spille mobilspil, mens der var oplægsholdere på. Disse handlinger mødes underviserne også med, når de afholder forløb for studerende, og en væsentlig metarefleksion, der kom til udtryk fra en af deltagerne, var, om det er de studerendes handlinger, der 'smitter' af på underviserne, eller om det er omvendt.

Kompetenceudviklingsforløbet havde primært som mål, at deltagerne i en CoI-ramme og igennem iterative processer skulle udvikle sig inden for e-didaktik og teknologi med henblik på at udvikle nye handlemåder ift. blended learning. Som det er fremgået, blev projektgruppen og deltagerne selv undervejs i forløbet opmærksomme på et sekundært mål, nemlig det lærerige ved at opleve 'selv at være studerende', og 'smage sin egen medicin'. Disse handlinger affødte en række metarefleksioner, der måske fremadrettet kan være med til at udvikle en alternativ gøren i forhold til det, underviseren 'plejer'. Læringsteoretisk og forskningsmæssigt er kritiske selvrefleksioner og metarefleksioner oftest blevet italesat som et positivt element at stræbe mod med hensyn til at udvikle sine og gruppens kompetence (Garrison \& Akyol, 2015; Musaeus \& Kristensen, 2005). En oplevelse fra dette kompetenceudviklingsforløb er således, at vi måske som undervisere glemmer at udsætte os selv for det, som vi udsætter andre for - husk at skriv portfolio, husk at aflevere opgaver, læs engelske tekster, rollespil i undervisningen mv., eller at vi i vores ivrighed efter at ville udsætte os selv for det, som vi også vil udsætte andre for, helt glemmer, at erfaringsgrundlaget for at opleve de samme konsekvenser af handlinger ikke er ens (Dazzani, 2005). Kompetenceudviklingsforløbet har ikke her et endegyldigt svar på, hvordan dette element operationaliseres til fulde. Erfaringerne fra forløbet viser dog, at deltagerne fandt det positivt, at få lov til at nå en form for fælles erkendelse ift. nogle af de handlinger, de selv påfører andre.

\section{Organisatorisk element}

Kompetenceudviklingsforløbet havde flere organisatoriske elementer, men især den budgetmæssige ramme på 102 lektioner pr. deltager har givet anledning til refleksion. Hensigten var ift. uddannelserne at dække evt. omkostninger, ved at deltagerne skulle medvirke i forløbet, og uddannelserne dermed skulle have andre til at varetage eksisterende arbejdsopgaver, som fx. undervisning og vejledning. Budgettet skulle altså hjælpe uddannelsesstederne til at kunne fritage medarbejderne fra nogle arbejdsopgaver, sådan at disse kunne være deltagende i kompetenceudviklingsforløbet. Erfaringerne viste dog, at nogle deltagere følte, at kompetenceudviklingsforløbet blev lagt oven i deres eksisterende arbejdsportfølje, og at de derved havde svært ved at være deltagende i hele forløbet. Nogle deltagere ytrede også, at de ikke var bekendt med de budgetmæssige forhold i projektet. Dette peger på, at der måske burde være skabt en bedre dialog omkring de budgetmæssige forhold i projektet, sådan at deltagerne og deres nærmeste ledere havde været helt klar over de rammemæssige forhold.

\section{Evaluering}

I forløbet blev benyttet både formative og summative evalueringer mhp. at få en indikation på, hvorvidt deltagerne havde fået udbytte af forløbet. Eftersom gruppen var lille, 24 personer, hvoraf 19 deltog i den afsluttende evaluering, vil der i vores optik ikke være et brugbart udbytte af en statistisk analyse. Evalueringerne, både de formative og den summative, er således netop kun en indikation på udbyttet. De formative evalueringer bestod i, at der mundtligt undervejs afslutningsvis på f2f dagene blev spurgt, hvorvidt der var tilfredshed med dagens forløb, og om der var forslag til ændringer. Herudover evaluerede projektgruppen de enkelte dage direkte i forlængelse af dagen og igen på gruppens planlægningsmøder. Summativt på sidste f2f skriftligt i form af en kvantitativ fronter-evaluering (Jensen, A. W., Larsen, S. J., Aagren, T. R. \& Nissen, J. O., 2018) med en efterfølgende mundtlig dialog. 
Den skriftlige del bestod af kvantitative spørgsmål med mulighed for kvalitativ uddybning. Evalueringen var ift. kompetenceudviklingsforløbets mål (jf. afsnittet "Del af udviklingsprojektet der gik forud for kompetenceudviklingsforløbet”). Spørgsmålene er her gengivet:

Tabel 2. Evalueringsspørgsmål.

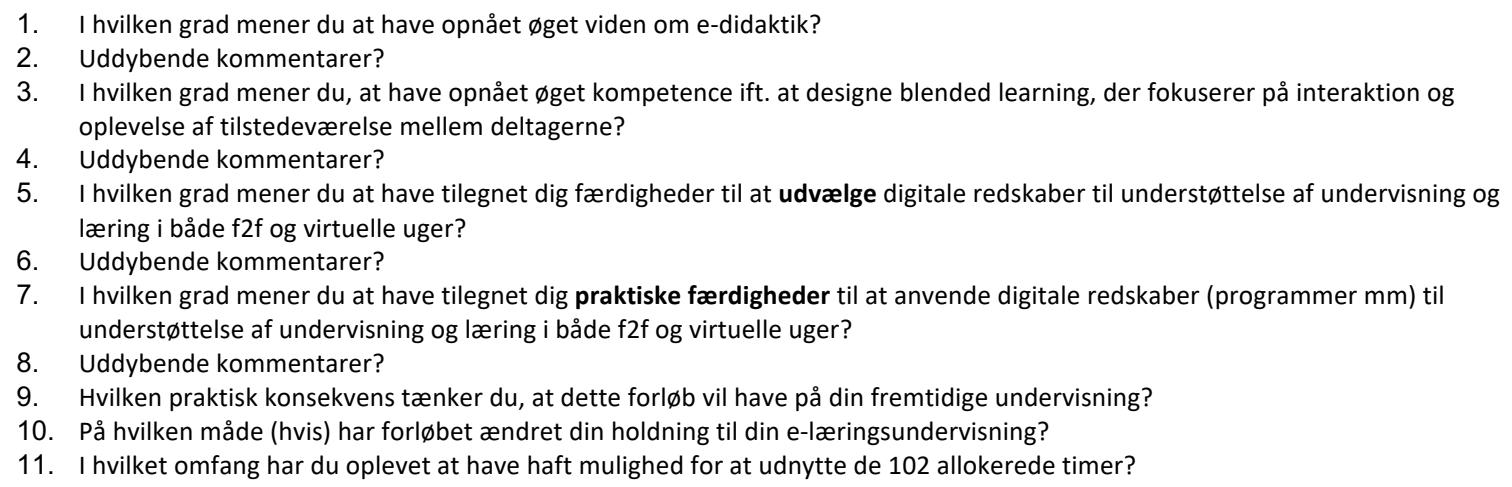

Evalueringerne tydede på en udbredt tilfredshed med forløbet. Svarene pegede på, at det var individuelt lige præcis, hvor underviserne mente, de havde profiteret mest. De helt nye e-undervisere syntes - ikke overraskende - at have fået det største samlede udbytte, altså både ift. e-didaktik og teknologi. Derudover fremgik det af både den skriftlige del og den efterfølgende mundtlige dialog, at en stor del af underviserne havde følt sig udfordret ift. muligheden for at udnytte de allokerede timer.

Ift. kompetenceudviklingsforløbets mål (jf. afsnittet "Del af udviklingsprojektet der gik forud for kompetenceudviklingsforløbet”) tydede evalueringerne således på, at deltagerne opnåede både viden om e-didaktik og færdigheder til at udvælge og benytte diverse redskaber, men som nævnt i varierende grad afhængig af deres niveau ved forløbets start. Målet om bidrag til udvikling af en fælles designskabelon blev nået gennem det fælles arbejde på f2f-dagene.

Deltagernes øgede viden og færdigheder er naturligvis relative, og nedenfor kommer vi ind på det ønskværdige i, at kompetenceudviklingsforløbet havde været længere med større udbytte til følge.

\section{Erfaringsopsamling og udviklingsmuligheder}

Dette afsnit vil kort skitsere nogle af de miljøafgrænsede erfaringer, som kompetenceudviklingsforløbets processer har afstedkommet. Disse perspektiver kan opfattes som et erfaringsgrundlag, som kommende lignende kompetenceudviklingsforløb måske kan udvikle videre på. Med andre ord er der tale om input til at udvikle tværprofessionelle kompetenceudviklingsforløb i uddannelsesmiljøer.

Erfaringerne er her struktureret i et overordnet niveau omhandlende den grundlæggende planlægning og et mere konkrete planlægningsniveau:

\section{Det overordnede niveau}

Det synes at have været udbytterigt at inkludere deltagere fra forskellige uddannelser. Som afsnittet om afvikling påpegede, gav deltagernes forskellige forankringer anledning til undren, diskussioner og problematiseringer, som formentlig ikke i samme omfang ville være opstået, hvis deltagerne havde været fra samme uddannelse. Diskussionerne ser vi, projektgruppen, som åbninger mod en øget refleksion ift. egen praksis, hvilket netop er ønskeligt set i et CoI-perspektiv (Garrison, 2016).

Kompetenceudviklingsforløbet havde to rammesatte gennemløb af undervisernes didaktiske design. For at udvikle, kritisere, problematisere og øge den demokratisk dialog om, hvad der virker hensigtsmæssigt 
i blendede læringsforløb endnu mere, kunne det, jf. DBR-tænkningen, måske være udbytterigt at have flere gennemløb, fx. ved at have flere moduler i kompetenceudviklingsforløbet. Herved ville der blive tale om dels yderligere udvikling, dels konsolidering af den erhvervede viden mv.

Det ledelsesmæssige engagement bør styrkes. Aktører med ledelsesmæssigt ansvar over og involvering i kompetenceudviklingsforløbet og dets deltagere bør sættes ind i det teoretiske udgangspunkt, som DBR-metoden repræsenterer, samtidig med at de også bliver gjort til en større del af forløbet. Dualistiske opdelinger mellem projektgruppe, deltagere og ledelse kan virke uhensigtsmæssige i et miljø, der tilstræber en mere samarbejdende og dialogisk struktur. DBR-metoden udarbejdes i miljøet, af miljøet (Barab \& Squire, 2004), hvorfor ledere, chefer og andre autoritative skikkelser med fordel kan inkorporeres i projektet, sådan at de også kan blive en del af de iterative processer. Forankringen undervejs og fremadrettet kunne dermed tænkes at blive stærkere, idet ledelse og deltagere ville have en større fælles forståelse for bl.a. didaktiske elementer, timeforbrug og samarbejdsorganiseringer. En styrkelse af ledelsesengagementet ville forhåbentlig bl.a. give deltagerne mulighed for at udnytte de allokerede timer og dermed opnå det optimale udbytte samt sikre forankringen og fortsættelsen af påbegyndt udvikling.

\section{Det konkrete planlægningsniveau}

Forløbet havde en fælles diskussionsramme med en tæt sammenknytning af e-didaktisk \& teknologisk kompetenceudvikling, og deltagerne skulle med sparring fra andre udarbejde design, der var relevante og umiddelbart anvendelige i den enkeltes egen praksis. Sparringen og den fælles ramme kvalificerede de enkelte design i de grupper, hvor det fungerede, mens den fælles ramme i form af design"skabelonen" i sig selv var en støtte for deltagerne i de grupper, hvor samarbejdet var mindre velfungerende. Uden undtagelse oplevede deltagerne, at det var udbytterigt at arbejde ud fra egen praksis og derved på samme tid udvikle egne kompetencer og arbejde med sin daglige undervisningstilrettelæggelse. I et fremadrettet forløbsgentagelsesperspektiv kunne man overveje om didaktikdiskussionerne burde styrkes. Som påpeget ovenfor anser vi diskussionerne for at være åbninger mod øget refleksion, men såfremt man havde flere moduler til rådighed, ville en accentuering af didaktikaspektet måske bringe deltagerne videre ift. deres praksis med studerende. Ift. det afviklede forløb med to moduler, kan man tvivle på, om deltagernes undren og diskussioner har sat aftryk på deres egen praksis med studerende.

Afviklingen af projektet viste, at man ikke kan forvente, at deltagende undervisere uden videre kan få gruppearbejde til at fungere, selv om de på daglig basis opererer med gruppearbejde ift. de studerende. Dette peger på nødvendigheden af som projektgruppe at tage endnu mere hånd om gruppesamarbejdet, end tilfældet var i det afviklede forløb.

Forløbet var planlagt som eksemplarisk i forhold til undervisernes egen praksis, hvilket efter projektgruppens vurdering og adskillige undervisertilkendegivelser fungerede godt. De tilbagevendende metarefleksioner var ikke på forhånd planlagt, men de viste sig hurtigt at være værdifulde refleksionsafsæt ift. at tænke undervisernes undervisningspraksis med studerende på en ny måde, ud fra egne oplevelser som "studerende". Afsnittet med titlen "metarefleksioner" har udfoldet, hvorledes forskellige forhold, der måske ellers ville være forblevet uitalesatte, blev diskuteret. Det gælder fx årsager til manglende studiedeltagelse, udfordringer med at fă gruppearbejdet til at fungere, værdien af at få andre øjne på sit arbejde samt behovet for eksplicitering af de logikker, man organiserer sine virtuelle rum efter. En meget vigtig erfaring fra forløbet er således det udbytterige i som underviser til stadighed at bringe sig selv i "studerende-position" og knytte refleksioner over deltagelse og læring til en sådan deltagelse - uanset om det sker i professionelt regi eller i fritiden.

En vigtig konklusion ift. "metarefleksioner" bliver dermed, at både f2f-tiden og gruppesamarbejdet skal give plads til divergerende holdninger og mulighed for at dele metarefleksioner, og at der i forløbet netop 
bør sættes tid af og skabes mulighed for, at disse refleksioner kan opstå, også i grupperegi. Dette peger på behovet for, at projektgruppen rammesætter og kontinuerligt understøtter gruppernes mulighed for at organisere og gennemføre gruppearbejdet, og at arbejdet for grupperne indbefatter et fokus på fx divergerende læringsforståelser. En vigtig pointe er endvidere, at gruppearbejdet bør lægge op til, at undervisernes praksis med studerende afdækkes, og at forløbet struktureres mhp. at muliggøre disse afdækninger.

Afslutningsvis kan det således konkluderes, at det DBR- og pragmatismeforankrede kompetenceudviklingsforløb i mange henseender forløb som ønsket og med et øjensynligt godt udbytte for deltagerne, men at det samtidig har givet anledning til vigtige indsigter og pointer både ift. det konkrete forløb og i forhold til planlægning af lignende fremtidige forløb.

\section{Referencer}

Amiel, T., \& Reeves, T. C. (2008). Design-Based Research and Educational Technology: Rethinking Technology and the Research Agenda. Journal of Educational Technology \& Society, 11(4).

Anderson, T., \& Shattuck, J. (2012). Design-Based Research A Decade of Progress in Education Research? Educational Researcher, 41(1), 16-25.

Barab, S. \& Squire, K. (2004). Design-Based research: Putting a Stake in the Ground. The Journal of the learning sciences, 13(1), 1-14.

Brinkmann, S. (2006). John Dewey. En introduktion. København. Hans Reitzels Forlag.

Broström, S. (2017). Didaktik for skolepædagoger. København. Hans Reitzels Forlag.

Cherryholmes, C. H. (1999). Reading Pragmatism. New York. Teachers College Press.

Cherryholmes, C. H. (1994). Pragmatism, Poststructuralism, and Socially Useful Theorizing. Curriculum Inquiry, Vol. 24, No. 2, 193-213.

Cherryholmes, C. H. (2013). What to teach. Theory \& Research in Social Education, 41:4, 566-574

Colucci, E. (2007). "Focus Groups Can Be Fun": The Use of Activity-Oriented Questions in Focus Group Discussion. Qual Health Res 2007 17: 14-22.

Curtin R, Presser S, Singer E. The effects of response rate changes on the index of consumer sentiment. Public Opin Q. 200o;64(4):413-28.

Dazzani, V. (2005). Learning and abduction. Semiotica 153-1/4, s. 73-84

Dewey, J. (1908). What Does Pragmatism Mean by Practical? The Journal of Philosophy, Psychology and Scientific Methods, Vol. 5, No. 4, s. 85-99.

Dewey, J. \& Dewey, E. (1915). Schools of tomorrow. New York, E. P. Dutton \& company. 681 Fifth Avenue.

Dohn, N. B., \& Hansen, J. J. (2016). Begrebet "Didaktisk design". I: Dohn, N. B. \&. J. J. Hansen, (red.), Didaktik, design og digitalisering. Samfundslitteratur.

EMU Danmarks læringsportal, SMTTE-model: https://arkiv.emu.dk/modul/en-hj\%c3\%a6lp-tilplanl\%c3\%a6gningen-med-smtte-modellen

Garrison, D. R., Anderson, T., \& Archer, W. (1999). Critical Inquiry in a Text-Based Environment: Computer Conferencing in Higher Education. The Internet and Higher Education, 2(2-3), 87-105.

Garrison, D. R. (2016). Thinking Collaboratively - Learning in a Community of Inquiry. New York. Routhledge.

Garrison, D. R. \& Akyol, Z. (2015). Developing a shared metacognition construct and instrument: Cenceptualizing and assessing metacognition in a community of inquiry. Internet and higher Education, 24, s. 66-71.

Halkier, B. (2016). Fokusgruppeinterview. Samfundslitteratur.

Hiim, Hilde og Hippe, Else (2002). Undervisningsplanlægning - for faglærere. København. Gyldendal.

Jensen, A. W., Larsen, S. J., Aagren, T. R. \& Nissen, J. O. (2018). Absalon E. Delrapport III, efterår 2018. Professionshøjskolen Absalon.

Jungk, R. (1998). Håndbog i fremtidsværksteder. København, politisk revy.

Jørnø, R. L. \& Gynther, K. (2018). Hvordan kan teknologi påvirke pædagogiske og didaktiske praksisser? Læring $\& \operatorname{Medier}(L O M)-n r .18-2018$

Laurillard, D. (2012). Teaching as a Design Science. Building Pedagogical Patterns for Learning and Technology. New York, Routledge.

Laurillard, D. (2016). The educational problem that MOOCs could solve: professional development for teachers of disadvantaged students. Research in Learning Technology Vol. 24, 2016.

Mead, G. H. (1934). Mind, Self and Society - from the standpoint of a Social Behaviorist. University of Chicago Press. 
Moon, J. (1999). Learning from learning journals. Learning Journals - A Handbook for Academics, Students and Professional. Development. London. Kogan Page ltd.

National Survey of Student Engagement: http://nsse.indiana.edu (lokaliseret 10.9.18)

Morton, S. M. B., Bandara, D. K., Robinson, E. M., \& Carr, P. E. A. (2012). In the 21st Century, what is an acceptable response rate? Australian and New Zealand. Journal of Public Health, 36(2), 106-108.

Musaeus, P. \& Kristensen, O. S. (2005). Transformativ og ekspansiv læring i to voksenlæringsmiljøer. Psyke \& Logos, 26, 714-729.

Pool, J. \& Laubscher, D. (2016). Design-based research: is this a suitable methodology for short-term projects? Educational Media International. VOL. 53, NO. 1, 42-52.

Nortvig, A.-M. (2017). Absalon E Projektbeskrivelse. Intern publikation.

Putnam, H. (1995). Pragmatism - An Open Question. Massachusetts. Blackwell Publishers Ltd.

Rorty, R. (1982). Consequences of pragmatism. Minneapolis. University of Minnesota Press.

Salmon, G. (2013). E-tivities. The key to active online learning. 2. udgave. Taylor og Francis Ltd.

Salmon, G. (2014). Learning Innovation: A Framework for Transformation. European Journal of Open, 17(2), 219-1027.

Salmon, G. (2016). The realm of learning innovation: A map for Emanators. British Journal of Educational Technology, 47(5), 829-842.

Skinner, B.F. (1971). Beyond Freedom and Dignity. Penguin Books.

UCSJ Kvalitet (2015). Kvalitetspolitik for e-læring. University College Sjælland.

Wang, F. \& Hannafin, M. J. (2005). Design-Based Research and Technology-Enhanced Learning Envioronments. ETR\&D, Vol. 53, No. 4, pp. 5-23.

Watts, L. (2016). Synchronous and Asynchronous Communication in Distance Learning. A Review of the Literature. The Quaterly Review of Distance Education, Volume 17 (1), 2016, s. 23-32.

Wright, G. (2015). An empirical examination of the relationship between nonresponse rate and nonresponse bias. Statistical Journal of the IAOS 31 (2015) 305-315 305.

Zilka, G. C., Cohen, R. \& Rahimi, I. D. (2018). Teacher Presence and Social Presence in Virtual and Blended Courses. Journal of Information Technology Education, Research. Volume 17, 2018. S. 103-126. 


\section{Forfattere}

\section{Anne Winther Jensen}

Lektor, ph.d.

Center for Pædagogik, Professionshøjskolen Absalon

\section{Jan Ohrt Nissen}

\section{Lektor}

Center for Sygepleje, Professionshøjskolen Absalon
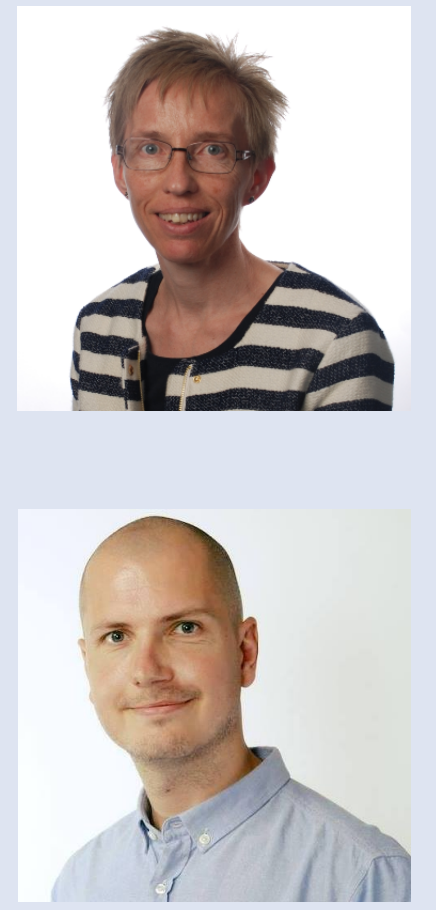